\title{
Needs Assesment of Adolescent Health Services
}

\author{
Khoiriyah Isni, Lina Handayani \\ Faculty of Public Health, Univesitas Ahmad Dahlan, Yogyakarta, Indonesia
}

\begin{tabular}{l} 
Article Info \\
\hline Article history: \\
Received Jan 18, 2017 \\
Revised Feb 20, 2017 \\
Accepted Feb 27, 2017 \\
\hline
\end{tabular}

\section{Keyword:}

Adolescent

Healthy Lifestyle

HIV/AIDS

Need Assesment

Reproductive Health

\begin{abstract}
Health problems surround the adolescent rises everytime, yet it does unexcelled with their awareness or knowledge about that problems. The adolescent health service that are poorly accesced by the adolescent become the indicator that proves that the adolescent health services are not fully known and utilized yet. The assesment of adolesccent health services need has to be done so that it can be fully understand by the helper, target and stakeholder. This study aimed to analyse the adolescent health service need in Karang Bendo, Banguntapan, Bantul, Yogyakarta, Indonesia. The study was conducted in 2016 using cross-sectional approach. The results revealed that the level of adolsecent's knowledge are still relatively poor: reproductive health knowledge (44.1\%), HIV/AIDS (41.2\%), smoke (50\%), drugs $(58.8 \%)$, and healthy lifestyle () $(47.1 \%)$. The majority of respondents said that they need health services about reproduction health (94.1\%), HIV/AIDS (91.2\%), smoke (91.2\%), drugs (88.2\%) and healthy lifestyle (91.2\%).
\end{abstract}

Copyright $@ 2017$ Institute of Advanced Engineering and Science. All rights reserved.

\section{Corresponding Author:}

Khoiriyah Isni,

Faculty of Public Health,

Universitas Ahmad Dahlan,

Jl. Prof Soepomo, Janturan, Warungboto, Yogyakarta, Indonesia.

Email: khoiriyah.isni@ikm.uad.ac.id

\section{INTRODUCTION}

Adolescent and their problems about reproduction health and sexuality, such as risked sexual behaviour, smoking, drugs, and physical abuse with adolescents's first pregnancy has been the main topic this day [1]. Beside that, the healthy and clean lifestyle become the influence of adolescent problems. Sexuality Study Center of Perkumpulan Keluarga Berencana Indonesia (PKBI) in Yogyakarta states that there is a change of adolescent's opinion about sex before marriage. About $3.4 \%$ of adolescents in Yogyakarta confess that they are having sex once. Meanwhile, other information has been informed by Head of Division senior and high education of Education, Youth and sports affairs Ministry of Yogyakarta, that in 2013 there are 325 cases of unwanted pregnancy happened to adolescents [2]. Beside that, HIV case in Yogyakarta reach to 615 people, whereas $44 \%$ of them was adolescents in age 15-29 years old [3]. That case was also happen in Bantul, where case of early-age marriage rises every year. It is caused by unwanted pregnancy. In 2011, number of under age marriage cases is 145 cases, then descending to 108 cases in 2012, and rise again in 2013 to 123 cases [4].

Another adolescent problems is smoking. Research to indicate that middle school student in Bantul Yogyakarta that once try to smoking reach to $39.5 \%$, now smoker $58.9 \%$ and the one who susceptible to smoke reach to $11.6 \%$ [5]. Beside the problems above, concumption of alcohol and risk sexual behaviour between the adolescents show that there is a strong relationship between consumption of alcohol and having risk sexual decision (multipartner sexual) and the unconsistently of self defense behaviour like the usi of condom [6].

Short of knowledge about health and health service also the right health information is the reason that caused of adolescent' problems mentioned above. Research that were done in 2 villages in Kamboja show that $92 \%$ of adolescents will looking for reproductive and sexual health service in the future. 
Especially, to them that already have sex before marriage experience. Only for $6.7 \%$ of adolescents visiting Primary health care, hospital or clinic to looking for health service to conquer their reproduction health problems [7]. That's why needs assesment of adolescents about health service needs is obligated. Adolescents that will be the main user of that service, in this study, will be given chance to speak up their opinion and perception, that will be the basic of information format structure and education about reproduction health and sexual lifestyle that match with psyche condition and characteristhic of adolescents [8]. This research aim to be the base of developing and making of policy about health care requisites that really needed by adolescent so that the execution can be optimal and right on target.

\section{RESEARCH METHOD}

This research type is an observational research using cross-sectional approach. Research was done at 2016 in Karang Bendo, Banguntapan, Bantul, Yogyakarta. The sample is 34 adolescents with range of age 15-24 years old that fulfill the inclusion criteria and taken with purposive sampling technique. Data collected using quisioner consist for some questions related to 1) adolescent health problems such as reproduction health; HIV/AIDS; smoke; drugs; and healthy and clean lifestyle, 2) health information source that accessed by adolescent, requisites level and adolescents opinion about health care for adolescent. Data analized by using univariat analysis for description of sampel characteristic.

\section{RESULTS AND ANALYSIS}

\subsection{Social Demography Characteristic}

Only $52.9 \%$ of respondent in $15-18$ years old, $55.9 \%$ of respondent is male and only $23.5 \%$ of respondent with low educational level and include in basic education category (unfinished from elementary school until completed middle school). Mostly respondent are student (85.3\%) of middle school, high school and college. The evaluation of respondent's activity in an adolescent organisation such as in civilization or in school still low, proved by $47.1 \%$ of respondent uninvolved in school organisation (70.6\%), and $61.8 \%$ uninvolved in other organisation as shown in Table 1.

Table 1. The Characteristic of Social Demography of Adolescent

\begin{tabular}{llcc}
\hline \multicolumn{1}{c}{ Characteristic } & \multicolumn{1}{c}{ Category } & $\mathrm{n}$ & Percentage $(\%)$ \\
\hline Age & Early adolescents & 18 & 52.9 \\
& Late adolescents & 16 & 47.1 \\
Sex & Male & 19 & 55.9 \\
Level of Education & Female & 15 & 44.1 \\
& Junior high school & 8 & 23.5 \\
Work status & Senior high school & 26 & 76.5 \\
& Student & 29 & 85.3 \\
Participation in adolescents & Working & 5 & 14.7 \\
community & Yes & 18 & 52.9 \\
Participation in OSIS (School & No & 16 & 47.1 \\
organization) & Yes & 10 & 29.4 \\
Participation in other organization & No & 24 & 70.6 \\
& Yes & 13 & 38.2 \\
\hline
\end{tabular}

\subsection{Respondent Knowledge}

Genarally, the level of adolescent's knowledge in Karang Bendo, Banguntapan, Bantul, Yogyakarta still low. Univariat analysis result as shown in Table 2 indicates that 1) $44.1 \%$ of respondent have low level of knowledge about reproduction health, 2) 41.2\% low in HIV/AIDS knowledge and, 3) $47.1 \%$ low in healthy lifestyle knowledge. However, half of respondent $(50 \%)$ have a good knowledge about smoke and $58.8 \%$ still categorized as low level in drugs knowledge.

This research measured the level of adolescents's knowledge related to adolescent health issues, i.e. reproduction health, HIV/AIDS, smoke, drugs and clean and healthy lifestyle. It aims to find out the level of adolescent's knowledge about the health issues that happening in society. Study result in knowledge variabel shows that there are respondents who still have a poor knowledge related to adolescents health issues.

Based on the answer to the questionnaire, 17 respondents (50\%) assume that breast is one of organ from woman reproductive organ and $32.4 \%$ of respondents doesn't know that urethra is one of male reproductive organ. Beside that, by $35.3 \%$ of respondents assume that masturbation is a serious health treat and respondent who think that condoms is the only contraception that can prevent pregnancy effectively by 
$32.4 \%$. The other research, 82 from 636 respondents (10.4\%) ever heard about masturbation, and only $18 \%$ respondents $(2.3 \%)$ who think that masturbation is a normal thing. About safe sex, only 89 respondents $(11.3 \%)$ who knowing correctly that condoms is one method that effective to perform safe sex [9].

Table 2. The Knowledge Level of Reproductive Health, HIV/AIDS, Smoke, Drugs and Healthy Lifestyle

\begin{tabular}{llcc}
\hline \multicolumn{1}{c}{ Characteristic } & Category & $\mathrm{n}$ & Percentage (\%) \\
\hline Knowledge of reproductive health & Good & 19 & 55.9 \\
& Bad & 15 & 44.1 \\
Knowledge of HIV/AIDS & Good & 20 & 58.8 \\
& Bad & 14 & 41.2 \\
Knowledge of Smoking & Good & 17 & 50 \\
Knowledge of Drugs & Bad & 17 & 50 \\
& Good & 14 & 41.2 \\
Knowledge of Healthy lifestyle & Bad & 20 & 58.8 \\
& Good & 18 & 52.9 \\
& Bad & 16 & 47.1 \\
\hline
\end{tabular}

Previous study in Malaysia states that all the respondents ever heard about HIV/AIDS, however they are different knowledge level. Respondents doesn't fully recognize and realize about HIV/AIDS disease transmission [10]. The report aligned with result in this research, wherein, 7 from 34 respondents assume that HIV/AIDS can be transmitted through alternately using cutlery and 35.3\% respondents think that HIV can be perevented by keep at the distance with HIV/AIDS patients, and 10 of respondents $(29.4 \%)$ not really sure that HIV can be transmitted from mother to baby.

Qualitative research at adolescent 18-24 years old about the negative consequences of smoking for health, respondents have moderate or sufficient level of knowledge, proved by some respondents believe that several systems in human body has a low tolerance on cigarettes. Respondents believe that smoke/cigarettes are daengerous to some people, and doesn't needed by many other poeple [11]. That result aligned with this research, 12 respondents $(35.3 \%)$ not sure that the substances contained in cigarettes can block enzymes work, and 13 respondents $(38.2 \%)$ not sure that acetone is a harmful chemicals that is contained in cigarettes. Nevertheless, as many as 20 respondents (58.8\%) respondents knew that the tar was the chemicals in cigarettes that can give the effect of addiction. However, 8 respondents (23.5\%) do not know the definition of passive smokers and there are respondents who do not sure and do not know that smoke can harm passive smokers $(20.6 \%)$. When adjacent to the active smokers, passive smokers will inevitably be affected. Smokers do not believe that smoking is very harmful to themselves and people around [12].

Beside cigarettes, drugs is one of the health problems faced by adolescents. Most respondents (98\%) provide a statement that drug use is not good for their health, and $67 \%$ of respondents agree and aware of the dangers. Responents also disagreed that drug use would make a person more confident and look cool. Studies on young people who use drugs, 64\% of respondents do not like the feeling generated after drug use, and $73 \%$ of respondents said that the drug does not make a person stronger. Meanwhile, another study says that very few children who know about the health hazards due to the use of drugs in the form of volatile [13].

Other adolescent health issues is a clean and healthy lifestyle, should have been known by all the people, not excluding adolescents. However, in contrast to the results of this study, which says that 11 respondents $(64.7 \%)$ did not know the definition of healthy lifestyle, and the majority of respondents $(85.3 \%)$ did not know the purpose of Healthy lifestyle, and are not sure that births attended by skilled health personal is one example of Healthy lifestyle indicator in households $(29.4 \%)$. Results of other studies conducted on students at a boarding school, showed that $54.5 \%$ of respondents included in the category that has an average level of knowledge related healthy lifestyle. This fact is happened because respondents who are categorized as average knowledge related to healthy lifestyle were aged 13-15 years, so it is considered not properly understand the importance of a clean and helathy lifestyle [14].

In general, knowledge of adolescents in relation to adolescents health issues (reproductive health, HIV/AIDS, smoking, drugs, and healthy lifestyle) in Karang Bendo, Banguntapan, Bantul, Yogyakarta into the category of bad. This is evidenced by the percentage of respondents who are knowledgeable good, none exceeds $75 \%$ for each of the health problems of adolescents. One of the factors that influence is their age is still relatively early teens, so it is still not aware of the importance of knowledge about adolescent health. In addition, the status of adolescents who are still studying and working impediments to coordinate a good time to get together. Then, the number of adolescents who are not involved in any youth organization makes the youth lacking in knowledge, relationship, and skills in dealing with various problems of adolescents. Supposedly, we need a training that aims not only to increase the knowledge, but also to improve the skills and life skills of adolescents.

IJPHS Vol. 6, No. 1, March $2017: 72-77$ 


\subsection{Needs of Adolescent Health Service}

Almost of all respondent say that they needs health service that focus on adolescent health issues. Univariat analysis result as shown in Table 3, shows that almost all of adolescent in Karang Bendo, Banguntapan, Bantul, Yogyakarta needs adolescent health service, 94.1\% for reproduction health service; HIV/AIDS, smoke, healthy lifestyle service $91.2 \%$ and drugs $88.2 \%$.

Table 3. Needs of Adolescent Health Services in Karang Bendo, Banguntapan, Bantul, Yogyakarta

\begin{tabular}{llcc}
\hline \multicolumn{1}{c}{ Characteristic } & \multicolumn{1}{c}{ Category } & $\mathrm{n}$ & Persentage (\%) \\
\hline Reproductive health services & Yes & 32 & 94.1 \\
HIV/AIDS services & No & 2 & 5.9 \\
\multirow{2}{*}{ Smoke services } & Yes & 31 & 91.2 \\
& No & 3 & 8.8 \\
Drugs services & Yes & 31 & 91.2 \\
\multirow{2}{*}{ Healthy lifestyle () services } & No & 3 & 8.8 \\
& Yes & 30 & 88.2 \\
& No & 4 & 11.8 \\
& Yes & 31 & 91.2 \\
\hline
\end{tabular}

Univariat analysis result as shown in Table 4 shows that discussion between friends of the same age is a form of health care that adolescent in Karang Bendo, Banguntapan, Bantul, Yogyakarta want. Furthermore, followed by face-to-face counseling $(85.3 \%)$, private counseling $(61.8 \%)$ and social media $(67.6 \%)$

The result supported with data analysis result about health care service that adolescent want, Primary health care or hospital and school or college $88.2 \%$. Special or private room like counseling room $70.6 \%$. In line with that result, health officer is a source of information that adolescent want most $(97.1 \%)$, other resources are parents and teacher $(88.2 \%)$, and also peer $(79.4 \%)$.

Table 4. Health Service Form

\begin{tabular}{|c|c|c|c|c|}
\hline \multicolumn{2}{|r|}{ Characteristic } & Category & $\mathrm{n}$ & Persentage $(\%)$ \\
\hline \multicolumn{5}{|c|}{ Form of services } \\
\hline \multirow[t]{2}{*}{ a. } & Discuss with friends & Yes & 32 & 94.1 \\
\hline & & No & 2 & 5.9 \\
\hline \multirow[t]{2}{*}{ b. } & Face to face (counseling) & Yes & 29 & 85.3 \\
\hline & & No & 5 & 14.7 \\
\hline \multirow[t]{2}{*}{ c. } & counselling & Yes & 21 & 61.8 \\
\hline & & No & 13 & 38.2 \\
\hline \multirow[t]{2}{*}{ d. } & sosial media & Yes & 23 & 67.6 \\
\hline & & No & 11 & 32.4 \\
\hline \multicolumn{5}{|c|}{ Place of services } \\
\hline \multirow[t]{2}{*}{ a. } & health services (Primary health care, hospital) & Yes & 30 & 88.2 \\
\hline & & No & 4 & 11.8 \\
\hline \multirow[t]{2}{*}{ b. } & School or campuss & Yes & 30 & 88.2 \\
\hline & & No & 4 & 11.8 \\
\hline \multirow[t]{2}{*}{ c. } & Special room (Counselling room) & Yes & 24 & 70.6 \\
\hline & & No & 10 & 29.4 \\
\hline \multicolumn{5}{|c|}{ Information sources } \\
\hline & Health workers & Yes & 33 & 97.1 \\
\hline & & No & 1 & 2.9 \\
\hline \multirow[t]{2}{*}{ b. } & Parents or teacher & Yes & 30 & 88.2 \\
\hline & & No & 4 & 11.8 \\
\hline \multirow[t]{2}{*}{ c. } & Peer & Yes & 27 & 79.4 \\
\hline & & No & 7 & 20.6 \\
\hline
\end{tabular}

In fact, adult do needs health service that is devoted to teens, as well as childern under five and the elderly who have special health care according to age. Proved that most of the respondents expressed needs for adolescent health services, namely health services for reproductive health, HIV/AIDS, smoking, drugs and healthy and clean lifestyle. Meanwhile, health services form that mostly desirable is discussion with peers, education, counseling and through social media. These result are in line with the desire of adolescents towards the right place to get the service. Such as Primary Health Care or hospital is the most desirable place by adolescents in Karang Bendo, Banguntapan, Bantul, Yogyakarta to obtain the adolescents health services. During this time, the respondents did not know that in these places there are health services for adolescents, 
but some respondents who know, said that they were reluctant and embrassed to access the service. Another study stated, adolescents in low and middle income countries had a significant barrier to accessing health services related to reproductive health and sexual transmitted infections (STI). It is caused by a lack of knowledge of adolescents about reproductive health and STI. Adults also feel embarrassed and worried about getting neagtive stigma when accssing the health services [15].

Another factor to be considered related needs of adolescents to health services is a source of information. This study also aims to analyze the resources desired by adolescents in Karang Bendo, Banguntapan, Bantul, Yogyakarta. The results obtained revealed that health workers are the most desired by adolescents to provide a variety of information about the health of adolescents. Other sources of information desired by adolescents are parents, teachers and peers.

The success of adolescents health services are also affected by some parties that should engage proactively. It can not seen only from the side of the adolescent, or the service provider, even from stakeholders and the environment around it. However, the facts in the fields, those parties are not proactive in supporting and succeeding health service programs for adolescents. When viewed from the perspective of service providers, not entirely actively "pick up the ball" in the field, where they are still waiting for adolescents who comes to accessing health services. The results of the analysis and reviews related to the improvement of adolescents health services prove that the number of facilitators and barriers to improve the quality of adolescents health services are closely related to information, communication with the service provider, commitment of adolescents health services, regulations and standards, as well as the satisfaction of users of adolescents health services. Another obstacle is access to and utilization of services. The similarity in access to health services, included in minority groups are found only in spesific health issues [16].

Besides, adolescents and service provider, there are also peers as a source of information adolescents health. It can not be ignored, that the time to get together with good friends at school or campus, more that the time to get together with their parents or family. In line, other studies have shown that the main source of health information is a peer group (64.4\%), which is maybe invalid information [17]. A mistake in choosing friends can be bad for adolescents. Friends give a huge influence in relationship and knowledge of adolescents. Studies conducted by Oljira, et al (2010) reported that the main source of adolescents health information comes from friends and the media [18]. In contrast, if the influence of friends is good, then a adolescents can be good, for example, friends often invited to perform positive activities such as Adolescents Health Information Center (PIK-R). However, the fact of the research result related to PIK-R and Health Care for Youth program in Semarang, suggests that teens who become stakeholders are still in the category of 'observer' (support, power still weak and passive involvement) because they do not know what tasks which will be run and the absence of follow-up or sustainability of the stakeholders who are the decision maker.But,others study shows that, $18 \%$ respondents know about drugs from their family. Multivariate analysis showed that one of the factors associated with drug use continuously in adolescents is to have family members of drug users [19]. In fact, parents can be the role models for their children.

Other supporting research findings reported that the majority of respondents in the FGD (focus group discussion) are reluctant and uncomfortable to discuss adolescent health issues, especially reproductive health. In socio-cultural, open discussion with parents and others about reproductive health is very rarely done because the topic concerns about the moral and religious values of society. This leads to lack of skills and knowledge adolescent for making decisions to act when they faced with adolescent health problems [20]. In line, other research shows that family relationships are related to the perception of the peer group as a source of support, especially when individual growth is respected within an atmosphere of acceptance and support in the family. On the other hand, family life characterized by conflict and lack of support for individual development is related to an increased involvement with groups and more conformity to group pressure [21].

Adolescents in Karang Bendo, Banguntapan, Bantul, Yogyakarta, does not have a special auspices for gathering adults. Some of the factors that influence is, the differsity of adolescents's activities, and the lack of supprot from local stakeholders. The expectation of this research can be input to all elements of society in Karang Bendo, Banguntapan, Bantul, Yogyakarta, for more paying attention to adolescents. For example by forming a adolescents center.

\section{CONCLUSION}

Research finding showed poor adolescents' knowledge level regarding health issues such as reproductive health, HIV/ AIDS, smoking, drugs, and healthy lifestyle. The needs for health services based adolescent is perceived almost all adolescents who were respondents in this study.

IJPHS Vol. 6, No. 1, March $2017: 72-77$ 


\section{ACKNOWLEDGEMENTS}

The authors would like to thank for Reseacrh and Development Department of Ahmad Dahlan University, which has provided the research grants. We also thank to stakeholders in Karang Bendo, Bantul, Yogyakarta, Indonesia who had been supporting this research.

\section{REFERENCES}

[1] P. A. C. Rehg, et al., "Associations Between Multiple Pregnancies and Health Risk Behaviors Among U.S. Adolescents," Journal of Adolescent Health, vol/issue: 47(6), pp. 600-603, 2010.

[2] Mim, "PKBI mention has occure 325 unwanted pregnancy in Yogyakarta," Tribun Jogja, 2014.

[3] Wuri, "First Consorsium of Youth Care friendly in Indonesia," Radio Republik Indonesia, 2014.

[4] Sugiarto, "Early marriage in Bantul is High," Suara Mereka, 2013.

[5] H. Trisnowati, "Cigarette Advertising Exposure and Adolescent SMOKING BEHAVIOUR of Junior High School Student in Bantul District, Yogyakarta," Thesis, Yogyakarta: Pascasarjana Program, Public Health Science, Facult of Medicine, Universitas Gadjah Mada, 2011.

[6] L. M. Cooper, "Alcohol Use and Risky Behavior among College Students and Youth : Evaluating the Evidence," Journal of Studies on Alcohol, vol. 14, pp. 101-117, 2002.

[7] J. R. Lopez, et al., "Characteristics of youth sexual and reproductive health and risky behaviors in two rural provinces of Cambodia," Journal of Reproductive Health, vol/issue: 12(83), pp. 1-12, 2015.

[8] A. Tanjung, et al., "Adolescent Needs Information and Reproductive Health Services," Penelitian Need Assesment Research in Kupang, Palembang, Singkawang, Cirebon, Dan Tasikmalaya, 2001.

[9] K. Mittal and M. K. Goel, "Knowledge Regarding Reproductive Health among Urban Adolescent Girls of Haryana," Indian Journal Community Med., vol/issue: 35(4), pp. 529-530, 2010.

[10] Zulkifli S. N., et al., "Study on the impact of HIV on People Living with HIV, their families and community in Malaysia," Kuala Lumpur, United Nations, 2007.

[11] C. O. Egbe, et al., "Knowledge of the Negative Effects of Cigarette Smoking on Health and Well-Being among Southern Nigerian Youth," International Journal of Social Science and Humanity, vol/issue: 6(3), 2016.

[12] "Preventing Tobacco Use Among Youth and Young Adults: A Report of The Surgeon General," U.S. Department of Health and Human Services, Atlanta, 2012.

[13] A. Elkoussi and S. Bakheet, "Volatile Substance Misuse Among Street Children in Upper Egypt," Substance Use Misuse, vol/issue: 46(1), pp. 35-39, 2011.

[14] U. Azizah, "Relationship Between Students Knowledge About PHBS and Ustadz Role in Preventing Disease Scabies With Disease Prevention Behaviour (Study on Students in Pondok Pesantren Al Falah Silo Subdistrict Jember Regency)," Majoring of Health Promotion and Behavior Science, Public Health Faculty, Universitas Jember, 2012.

[15] A. N. Levinson, et al., "Sexually Transmitted Infection Services for Adolescents and Youth in Low- and MiddleIncome Countries: Perceived and Experienced Barriers to Accessing Care," Journal of Adolescent Health, vol. 59, pp. 7-16, 2016.

[16] D. Phil, et al., "Improving the Quality of Health Care Services for Adolescents, Globally: A Standards-Driven Approach," Journal of Adolescent Health, vol. 57, pp. 288-298, 2015.

[17] A. A. Rahman, et al., "Knowledge Of Sexual And Reproductive Health Among Adolescents Attending School In Kelantan, Malaysia," Southeast Asian Journal Trop Med Public Health, vol/issue: 42(3), 2011.

[18] L. Oljira, et al., "Assessment of comprehensive HIV/AIDS knowledge level among in-school adolescents in eastern Ethiopia," Journal of the International AIDS Society, vol. 16, pp. 17349, 2013.

[19] L. Embleton, et al., "Knowledge, Attitudes, and Substance Use Practices Among Street Children in Western Kenya," vol/issue: 47(11), pp. 1234-1247, 2012.

[20] A. Motuma, et al., "Utilization of Youth Friendly Services and Associated Factors Among Youth in Harar Town, East Ethiopia: A Mixed Method Study," BMC Health Services Research, vol. 16, pp. 272, 2016.

[21] A. Shulman, et al., "Peer Group and Family Relationships in Early Adolescence," International Journal of Psychology, vol/issue: 30(5), pp. 573-590, 2007. 